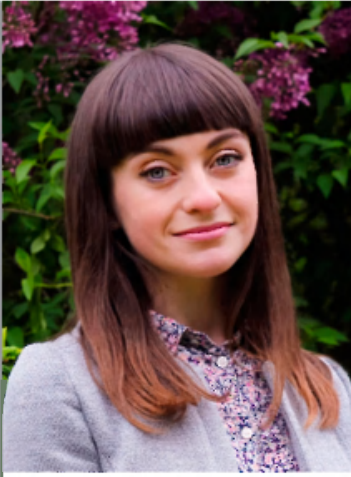

o. V. Polunina,

Post-graduate Student,

Uman National University of Horticulture (Uman), Ukraine

E-mail: a.polunina@ukr.net

УДК 303.22: $581.45: 634.11: 634.1 .03$ DOI $10.31395 / 2310-0478-2018-21-80-82$ PhD in Agricultural Sciences, Associate Professor, Uman National University of Horticulture (Uman), Ukraine

E-mail: volodymyr.maiboroda@udau.edu.ua

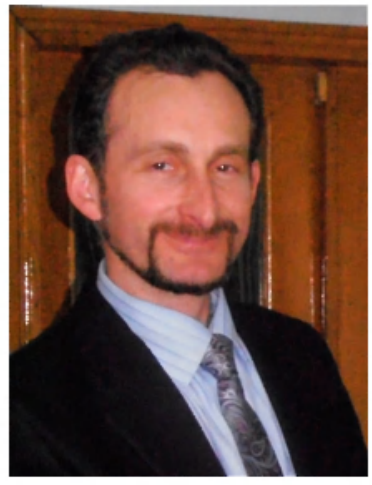

A. Y. Seleznov,

Chief Technology Officer at Petiole LTD, Ukraine

E-mail: andreii.seleznov@gmail.com

\title{
EVALUATION METHODS OF ESTIMATION OF YOUNG APPLE TREES LEAF AREA
}

The analysis of the three measurement methods of leaf blade area of young bi-axis apple trees on rootstock $54-118$ was made. High accuracy of the measurement results by a method of area calculation within a leaf contour on millimeter graph paper $\left(31,21 \mathrm{~cm}^{2}\right)$ and with help of a method of computer sight using application "Petiole" on Smartphone with operational system Android $\left(31,28 \mathrm{~cm}^{2}\right)$ was established. The gravimetric method and the use of mobile application "Petiole" appeared to be the most productive as to time consumption to carry out the operation.

Key words: leaf blade area, definition methods, computer sight, millimeter graph paper method, gravimetric method, "Petiole" application, bi-axis apple tree.

\section{О. В. Полуніна}

аспірант Уманського національного університету садівництва (м. Умань), Україна

В. П. Майборода

кандидат с.-г. наук, доцент Уманського національного університету садівництва (м. Умань), Україна

А. $\epsilon$. Селезньов

технічний директор ТОВ «Petiole», Україна

\section{ОЦІНКА МЕТОДІВ ВИЗНАЧЕННЯ ПЛОЩІ ЛИСТЯ САДЖАНЦІВ ЯБЛУНІ}

Проаналізовано три методи вимірювання площі листкової пластинки двопровідникових саджанців яблуні на підщепі 54-118. Встановлено високу точність результатів вимірювання методом підрахунку площі в межах контура листка на міліметровому папері $\left(31,21 \mathrm{~cm}^{2}\right)$ та за допомогою методу комп'ютерного зору із застосуванням додатку «Реtiole» на смартфоні з операційною системою Android $\left(31,28 \mathrm{~cm}^{2}\right)$. Найпродуктивнішими, щодо витрат часу на виконання операції, виявились метод «висічок» та застосування мобільного 'додатку «Petiole».

Ключові слова: площа листкової пластинки, методи визначення, комп'ютерний зір, метод «висічок», 'додаток «Реtіоlе», яблуня, 'двопровідникові саджанці.

\section{А. В. Полунина}

аспирант Уманского национального университета садоводства (г. Умань), Украина

В. П. Майборода

кандидат с.-х. наук, доцент Уманского национального университета садоводства (г. Умань), Украина

А. Е. Селезнев

технический директор 000 «Petiole», Украина

\section{ОЦЕНКА МЕТОДОВ ОПРЕДЕЛЕНИЯ ПЛОЩАДИ ЛИСТЬЕВ САЖЕНЦЕВ ЯБЛОНИ}

Проанализировано три метода измерения площади листовой пластинки двупроводниковых саженцев яблони на подвое 54-118. Установлена высокая точность результатов измерения методом подсчета площади в пределах контура листа на миллиметровой бумаге $\left(31,21 \mathrm{~cm}^{2}\right)$ и с помощью метода компьютерного зрения с применением приложения «реtiole» на смартфоне с операционной системой Android $\left(31,28 \mathrm{~cm}^{2}\right)$. Наиболее продуктивними, относительно затрат времени на выполнение операции, оказались метод «высечек» и применение мобильного приложения «Petiole»,

Ключевые слова: площадь листовой пластинки, методы определения, компьютерное зрение, метод «высечек», приложение «Petiole», яблоня, двупроводниковые саженцы. 
Introduction. Photosynthesis products amount to $90-95 \%$ of dry substances used by a plant to build all its organs (including yield) [Fridrih et al. 1983, Kondratenko 1997]. A leaf is one of the main assimilating organs of a fruit plant, the formation of which depends on a complex of influence factors - nutritive and water regime, planting density, lighting, crown shape, application of protection means and plant growth regulators and many others [Fridrih et al. 1983, Mohsenin 1986]. Consequently, leaf blade area serves as a certain indicator of a plant condition as well as its potential productivity. Up-to-date means are to guarantee the accuracy of the measurement results, which is why new encourages a researcher, first of all, to analyze and estimate them.

The methods of leaf blade area estimation, which are widely used in agricultural research of fruit crops, require considerable amount of time to do the measurement or they are allowable to a high error value [Klochkova et al. 2010].

In 1971 the following methods of leaf area estimation were described and analyzed by a group of Check scientists: leaf area calculation within their contours on millimeter graph paper, planimetric, photometric, use of linear leaf parameters, gravimetric, etc. [Sestak et al. 1971]. In particular, the difference of the methods as to their complexity, accuracy and productivity was stated [Moiseichenko \& Yeshchenko 1994].

Drawing a leaf contour on millimeter graph paper is one of the most accurate methods of leaf blade area estimation [Pandey \& Sing 2011], but its productivity is low [Moiseichenko \& Yeshchenko 1994].

Gravimetric "carvings" method, which is widely used for the majority of agricultural crops, is characterized with higher productivity [Moiseichenko \& Yeshchenko 1994]. The place on a leaf influences carving thickness; veins in the chosen carving place increases its mass; fast leaf shriveling results in mass loss and others [Klochkova et al. 2010].

The methods using the programs which are based on the analysis of scanned leaf pictures have become more common with the development of computer technologies [Klochkova et al. 2010, Nurminskaia et al. 2017]. These measurement methods are efficient for the crops with a leaf blade area which does not exceed a scanner size.

Ukrainian designer Andrii Seleznov suggested a modern method of leaf blade area estimation with help of "Petiole" application using a library of computer sight Open CV for Smartphone of Android system, which allows receiving data from leaf blade area both in the laboratory and in the orchard or the nursery in the regime of real time.

The development of new methods and the improvement of existing ones in the research in fruit production and in nursery studies in particular, are to enhance the productivity methods of the leaf blade area estimation appear, and this accuracy of this method depends on many factors: a chosen

of a scientific process at an experimental level, first of all, due to time-saving, spent on getting the results, and the accuracy increase of the received data. Besides, an important requirement for a present-day researcher is his/ her mobility, which is very much favored by the development of modern technologies.

Materials and methods. The research was carried out at the Department of Fruit Growing and Viticulture on experimental fruit nursery plot of Uman National University of Horticulture (Ukraine).

With the appearance of a new instrument - "Petiole" application on Smartphone - for leaf blade area estimation, the task was set to analyze its accuracy and efficiency in comparison with conventional methods: area calculation within leaf contours on graph paper and gravimetric method.

The analysis of the received data was made in the context of the experiment with growing annual young bi-axis apple trees, cv. Florina, on rootstock 54-188, depending on grafting height and the way two axis were formed. A twofactor trial has eight variants in a four-time replication. A sampling of ten leaves was taken from each experimental plot, 32 samplings all together. An area of each leaf was measured with three methods in succession.

The method of area calculation within leaf contours on millimeter graph paper was taken as the control. As the method allows saving leaf wholeness, it was used first.

Then, the method of computer sight with mobile "Petiole" application was used to estimate leaf blade area. The use of this method envisaged the following actions: Smartphone was placed on a fixed height over a white surface and Smartphone camera was calibrated with producers ${ }^{\prime}$ standard sheet. Later, a standard sheet was replaced with leaf blade, pressing it to the surface with glass or other transparent materials, and the area was estimated with the application. Total leaf area of one plant or a sampling was fixed with a separate function of the application.

The last to be used was gravimetric method, as it implied leaf blade damage. Getting data by this method consisted in the following processes: leaves were chosen in samplings, at least 10 leaves each, petioles were cut off, and then leaf blades were weighed. 20 carvings, made with help of a drill on both sides of the central vein, were received from a sampling of leaves, and later they were also weighed [Karpenchuk \& Melnik 1987]. Leaf blade area calculation was done by an equation [Moiseichenko \& Yeshchenko 1994]:

$$
S=\frac{M \times S_{1} \times n}{m \times N}
$$

where: $\mathrm{S}$ - leaf blade area, $\mathrm{cm}^{2}$; $S_{1}$ - area of one carving $\left(S_{1}=0,785 \cdot D^{2}\right.$, where $D$ - carving diameter, $\mathrm{cm}), \mathrm{cm}^{2} ; \mathrm{n}$ - number of carvings, pieces; $M-$ mass of leaves in a sampling, $\mathrm{g} ; \mathrm{m}$ - carving mass, $\mathrm{g} ; \mathrm{N}$ number of leaves in a sampling, pieces.

Results. The use of "Petiole" application and "carvings"

Таблиця 1

Timing results depending on the used methods of leaf blade area estimation of young bi-axis apple trees of Florina cultivar on rootstock 54-118, UNUH (2017)

\begin{tabular}{|l|c|}
\hline \multicolumn{1}{|c|}{ Method } & Leaf blade area, $\mathbf{c m}^{\mathbf{2}}$ \\
\hline $\begin{array}{l}\text { Area calculation within leaf contours on millimeter graph } \\
\text { paper (control) }\end{array}$ & 61.3 \\
\hline With help of "Petiole" application & 0.9 \\
\hline Gravimetric "carvings" method & 1.1 \\
\hline
\end{tabular}

Leaf blade area of young bi-axis apple trees, cv. Florina, on rootstock

54-118 depending on the method of indicator estimation, UNUH (2017)
Leaf blade area, $\mathrm{cm}^{2}$

31.21

\begin{tabular}{|l|c|}
\hline $\begin{array}{l}\text { Area calculation within leaf contours on millimeter graph } \\
\text { paper (control) }\end{array}$ & 31.21 \\
\hline With help of "Petiole" application & 31.28 \\
\hline Gravimetric "carvings" method & 32.01 \\
\hline
\end{tabular}




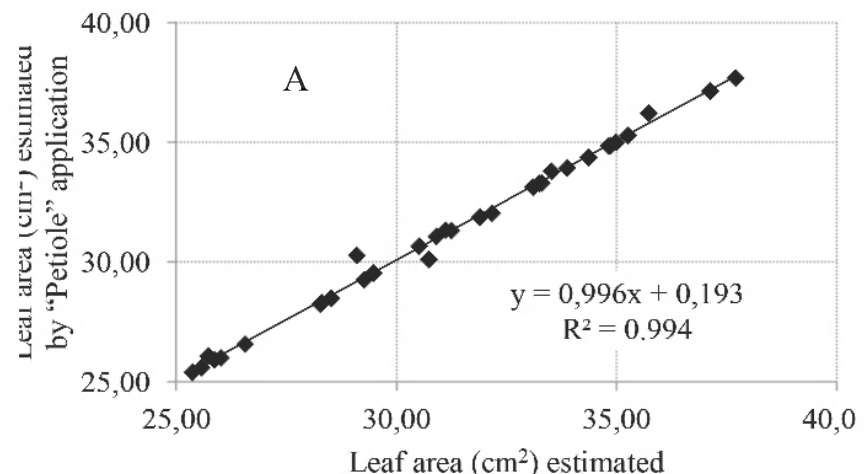

by millimeter graph paper method

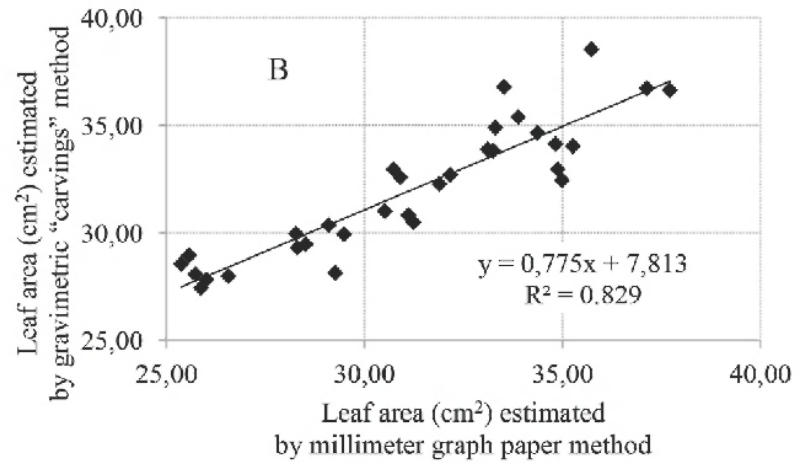

by millimeter graph paper method

Figure 1: Relationship between leaf area estimated by millimeter graph paper method and: A - leaf area estimated by "Petiole" application; B - leaf area estimated by gravimetric "carvings" method.

method helped reduce the time for leaf blade area estimation as compared with millimeter graph paper method (Table 1).

Table 1 . Timing results depending on the used methods of leaf blade area estimation of young bi-axis apple trees of Florina cultivar on rootstock 54-118, UNUH (2017).

In comparison with other methods, the use of "Petiole" application allowed minimizing an accuracy error of the received data due to the reduction of the effect of human factor on the measurement process. Thus, according to the results of leaf measurement of Florina apple tree on rootstock 54-118, the value, the closest to the control, was received with the use of "Petiole" application (Table 2 ). The deviation from the values of the control method was 0.08 $\mathrm{cm}^{2}$ or $0.22 \%$. Gravimetric "carvings" method showed a serious deviation from the control, namely, $0.80 \mathrm{~cm}^{2}$ or $2.56 \%$.

Relationships between leaf area estimated by gravimetric "carvings" method (dependent variable) and that estimated by millimeter graph paper method (independent variable) for thirty-two samplings as given in Figure 1 (B) show that the two sets of estimates are strongly related with each (R2 $=0.829$ ).

The closest relationships between leaf area estimated by "Petiole" application and leaf area estimated by millimeter graph paper method indicates the high accuracy of measurement using "Petiole" application (Figure $1(A)$ ). The coefficient of determination between the two sets of estimates prove that relationships are linear and significant $\left(R_{2}=0.994\right)$.

The method of use of "Petiole" application is more accurate, faster and nondestructive (saves leaf wholeness) and can be applied in nursery plot or orchard. An important factor which affect the accuracy of use of "Petiole" application is uniform lighting of the leaf blade under the camera so that there are no shadows that affect the data error.

Conclusions. In accordance with the results of the research it has been established that the method of leaf blade area estimation with help of computer sight and using Smartphone camera and "Petiole" application facilitates to get indicator values more efficiently and accurately, to decrease the number of hand manipulations, to reduce measurement time. The application of this method makes it possible for a researcher to improve labor productivity during measurement processes.

Acknowledgment. The authors thank Professor O.V. Melnyk for research assistance.

\section{Reference}

1. Fridrih, G., Noimand, D., Fogl, M. (1983) Fruit plant physiology. Translated from German under editorship of Kudriavets. Moscow. P. 130-148.

2. Karpenchuk G.K., Melnik A.V. Records, observations, analyses, data processing in the experiments with fruit and berry plants: Methodological recommendations. Uman, 1987, P. 12-13.

3. Klochkova, O. S., Solomko, O. B., Tsvetkov, G. V. (2010) Methodology of leaf area estimation. Innovations in the technologies of agricultural crop cultivation: proceedings of XI international scientific-practical conference of young scientists, master- and post-graduate students. P. 120. URL: http:// young scientists, master- and post-graduate students. P. 120. URL: http:// 18.06.2017)

4. Kondratenko, P. V. (1997) Productivity of the nursery of apple clonal rootstock depending on the ways of its laying down. Horticulture. Iss. 45. P. $54-60$

5. Mohsenin, N. N. (1986) Physical Properties of Plant and Animal Materials, Gordon and Breach Science Publishers, New York, USA, 1986. 31(7). P. 702.

6. Moiseichenko, V. F., Yeshchenko, V. O. (1994) Principles of research work in agronomy. Kyiv, 1994. P. 158-161.

7. Nurminskaia, Yu. V., Malkov, F. S., Bakhvalov, S. V. (2017) Automation of the morphology studies of plant leaves. News bulletin of universities. Applied chemistry and biotechnology. Vol. 7. no 1 (20). P. 56-60.

8. Pandey, S., Singh, H. (2011) A simple, cost-effective method for leaf area estimation. Journal of botany, 2011. №. 658240. P. 6.

9. Sestak, Z., Catsky, J., and Jarvis, P. G. (1971) Plant Photosynthesis Production, Mannual of Methods, Junk Publishers, The Hague, The Netherlands, 1971. $818 p$ 